\title{
Do Personality Traits Matter? A Comparative Study of Student Preferences for Teaching and Learning Activities and Assessment Modes in Two Different Majors
}

\section{ABSTRACT}

What do we need to know about our students to better provide for more equitable outcomes? Who will succeed depends on many factors, and student personality traits constitute one factor that has received less attention in the engagement and teaching literature. The aim of the present study is to add to discussions on teaching in higher education by exploring how students differ on personality trait profiles (IPIP-NEO-PI test), approaches to learning (R-SPQ-2F test), and preferences for teaching and learning activities and assessment modes. The online survey study was carried out at a Swedish teaching university on students in a business $(n=144)$ and preschool teacher education program $(n=179)$. The findings revealed systematic differences between the types of assessment modes preferred and significant differences between the two majors regarding learning approaches, motives, and strategies. The findings are examined in relation to models of learning and disjuncture, discussions of educational relationships and risk, and concepts of teaching and learning regimes. Teachers and curriculum developers face two issues. First, teachers who are new or come from a different teaching and learning regime may run the risk of alienating students and causing them extreme anxiety if they use teaching and learning activities and assessment modes students are uncomfortable and unfamiliar with. Second, teachers and curriculum developers run the risk of not challenging students enough, thus depriving them of valuable learning experiences.

\section{KEYWORDS}

personality traits, assessment modes, teaching and learning activities, approaches to learning, preferences

\section{INTRODUCTION}

Education entails risks of various kinds. Student risks learning something that may change his/her worldview or self (Biesta, 2005). They also risk learning nothing or failing, which entails costs to society, the university and the student (Simpson, 2006). What, then, do we need to know about our students to better provide for more equitable outcomes? Various factors are critical to academic success (Kahu, 2013; Kuh, 2009; Trowler \& Trowler, 2010), for example, intelligence (Rosander \& Backstrom, 2014), grade point average (e.g., Campbell \& Dickson, 1996; Kuncel, Crede, \& Thomas, 2007; McKenzie \& Schweitzer, 2001), demographic factors (e.g., Krause et al., 2005; Yorke, 2004; Yorke \& Longden, 2008), and social and academic integration (e.g., Thomas, 2012). 
One aspect less frequently discussed is student personality traits, which has also been found to affect academic success (e.g., Rosander \& Backstrom, 2014; Vedel, Thomsen, \& Larsen, 2015). Different people have different personality traits, and psychological research indicates that certain personality types are attracted to certain majors and professions (Holland, 1997; Vedel, 2016). This would seem to indicate that the composition of students, or their personality profiles, in different programs varies, which would presumably have implications for curriculum design and teaching (Vedel, 2016).

There is research on the personality traits of students in different majors (see Vedel, 2016, for a review), as well as on personality traits and learning approaches (i.e., Furnham, Monsen, \& Ahmetoglu, 2009), preference for types of teaching and learning activities (i.e., Chamorro-Premuzic, Furnham, \& Lewis, 2007) and for assessment modes (i.e., Furnham, Batey, \& Martin, 2011; Lakhal, Sevigny, \& Frenette, 2013). Influenced by this research, we posit that different programs attract different personality types and that, on the cohort level, students prefer different teaching and learning activities and assessment modes - preferences that have implications for curriculum development and teaching in the specific programs. Despite this, the personality profiles of student cohorts are rarely discussed in the higher education literature or courses. For example, in a sample of textbooks on teaching in higher education, (i.e., Biggs \& Tang, 2011; Elmgren \& Henriksson, 2016; Ramsden, 2003; Svinicki \& McKeachie, 2014), the word personality is not included in the indices.

The aim of the present study is to contribute to discussions on teaching in higher education by exploring how students in two different majors in a Swedish teaching university differ regarding their personality trait profiles, learning approaches, and preferences for teaching and learning activities and assessment modes. The particular contribution we make here is to explore the personality and learning approach profiles of student cohorts rather than focusing on the individual level, as well as to compare two majors: business administration and preschool teacher education. Moreover, we explore what modes they have actually experienced. We define a cohort as "the total population of individuals entering the specific environment at the same point of time" (Schaie, 1986). In this case, a cohort is an educational group of students following the same academic curriculum. Here it is important to note that, in the Swedish higher education system, students have little choice between courses; hence, a cohort is a group of students admitted into a program at a certain point in time, who are expected to graduate together after three years.

Finally, to more fully elaborate on the implications the present results may have for teachers and curriculum development in higher education, the results are discussed in relation to Jarvis's (2010) model of learning and disjuncture, Biesta's (2005) discussion on educational relationships and risk, and Trowler's (2008) concept of teaching and learning regimes.

More specifically, our four research questions are as follows:

1. On the cohort level, what differences are there in personality profiles between students from the two academic majors?

2. On the cohort level, what differences are there between the learning approaches of students from the two academic majors?

3. On the cohort level, what differences are there between preferences for teaching and learning activities and assessment mode among students from the two academic majors?

4. To what extent can student personality profiles explain assessment mode preferences? 


\section{LITERATURE REVIEW}

Because the aim of the present article is to discuss student cohort personality profiles and their possible implications for teaching and learning, the literature review first briefly discusses personality and its relation to academic choice, and then approaches to learning and preferences for teaching and learning activities and assessment modes in relation to personality. Thereafter, Jarvis's (2010) and Biesta's (2005) views on learning, risk and disjuncture are briefly presented.

\section{Personality}

In the present study, we used the "big five" model of personality, which identifies five traits: openness to experience (the tendency to involve oneself in intellectual activities and experience new sensations and ideas), conscientiousness (will to achieve, orderliness, responsibility), extroversion (preference for social interaction and lively activity and sociability), neuroticism (proneness for emotional instability), and agreeableness (friendly, considerate, and modest behavior) (Costa \& McCrae, 1992). These dimensions are stable across the lifespan and directly related to behavior (McCrae \& Costa, 1997). The "big five" model of personality is a current model and is the most studied and validated model in the scientific literature (Lakhal et al., 2013).

\section{Personality and academic choice}

It has been suggested that students choose an occupation based on how well their self-image matches the stereotypical image of the occupation (Hollander \& Parker, 1972). Later studies using the five personality traits have also found a correlation between personality and academic major (Costa \& McCrea, 1992; Vedel, 2016; Vedel et al., 2015). These studies confirmed "big five" score differences between students from different majors; they also found that, because the student respondents had just enrolled, the results also confirmed the claim that certain personality types are attracted to certain occupations (Hollander \& Parker, 1972). In previous research, business students have been found to score lower on neuroticism than do non-business majors. They also scored higher on extroversion and conscientiousness, but lower on agreeableness and openness (Lounsbury et al., 2009). Teacher education students have been found to be less extroverted, emotionally stable and conscientious than business students (Lakhal et al., 2013).

Students from different academic majors will later work in different professions with different demands for certain traits, such as interpersonal skills or creativity; the majors reflect this reality. It is plausible that different types of students flourish or fail depending on whether there is a good fit between their expectations and actual experience, that is, on whether or not they can develop into what they want to be. However, from a teaching and learning perspective, the most interesting question is what implications personality differences have for learning styles and, thus, for teaching and evaluation practices. This has not been discussed in previous studies.

\section{Approaches to learning}

Students' approaches to learning constitute a research perspective that originated in Europe and Australia, the aim being to try to understand how students tackle the task of learning. Approaches to learning comprise both a motive (why students learn) and a related learning strategy (what they do) (Biggs, 1987). 
A student may adopt a surface, or a deep, approach to satisfy the specific task in question, but individuals generally exhibit a tendency to take either a predominantly deep approach or a predominantly surface approach to learning (Marton \& Saljo, 1976). However, according to Biggs (1987), a well-aligned course and a well-balanced workload may encourage students to take a deep approach. However, the opposite situation may cause students, even those who normally prefer a deep approach, to adopt a surface approach to learning. Research indicates a link between a deep approach to learning and academic success, but the relationship is not unambiguous. Haarala-Muhonen et al. (2017) claimed there is more variation and found, for example, that students with a surface approach, but also those with a deep approach but who are unorganized, earned fewer credits than organized students who took a deep approach.

Kember, Biggs, and Leung (2004) presented a multidimensional hierarchical model of learning approaches, as shown in table 1 . The top level consists of two learning approaches: deep and surface. The next level adds the motive and strategy for each approach. At the lowest level, there are four different variants of motive and strategy for each approach. Deep learners enjoy taking an active orientation to the learning task, which is characterized by a search for meaning, a focus on the content as a whole and a willingness to see the interrelationship between different parts. A deep approach is based on interest in the task subject matter; the strategy is to maximize understanding and the intention is to engage in the task properly, on its own terms. A surface approach, on the other hand, is characterized by extrinsic motivation, a focus on the elements rather than the task as a whole, and a desire to complete the task as quickly as possible with the minimum of effort needed to meet requirements, which leads to a strategy of acquiring knowledge with a minimal emphasis on understanding (Biggs, 1987; Biggs, Kember, \& Leung, 2001).

Table 1. A hierarchical factor structure for approaches to learning, according to Kember et al. (2004)

\begin{tabular}{|c|c|c|c|c|c|c|c|}
\hline \multicolumn{4}{|c|}{ DEEP APPROACH } & \multicolumn{4}{|c|}{ SURFACE APPROACH } \\
\hline & motive & & strategy & sur & ce motive & surfac & strategy \\
\hline $\begin{array}{c}\text { intrinsic } \\
\text { interest }\end{array}$ & $\begin{array}{l}\text { commitment } \\
\text { to work }\end{array}$ & $\begin{array}{c}\text { relating } \\
\text { ideas }\end{array}$ & understanding & $\begin{array}{l}\text { fear of } \\
\text { failure }\end{array}$ & $\begin{array}{c}\text { aim for } \\
\text { qualification }\end{array}$ & $\begin{array}{c}\text { minimizing } \\
\text { scope of } \\
\text { study }\end{array}$ & memorization \\
\hline
\end{tabular}

\section{Relationships between approaches to learning and personality}

Regarding the relationships between approaches to learning and personality traits, research indicates that openness, as characterized by open-mindedness and active imagination, has a strong positive relationship with the deep approach (Zhang, 2003). Chamorro-Premuzic and Furnham (2009) discussed the positive association between openness and deep approaches: open individuals are characterized by higher creativity, imagination and intellectual curiosity. Another relationship is that between neuroticism and a surface approach, both reflecting negative emotionality and maladaptive coping responses (Diseth, 2003). According to Chamorro-Permuzic et al. (2007), neurotic students opt for a surface rather than a deep approach, as the latter may be hindered by worries and unfocused attention.

For teachers it would be relevant to know how student personality traits compete with situational factors, that is, how it may be possible to affect student approaches to learning. There is a discussion in the literature on whether learning approaches should be seen as a partially stable 
personal attribute (i.e., Diseth , 2003; Duff et al., 2004; Swanberg \& Martinsen, 2010) or as a strategic construct, that is, as determined by situational circumstances (i.e., Biggs \& Tang, 2011). ChamorroPremuzic et al. (2007) and Zhang (2003) have found that personality traits and learning approaches are related but nonetheless distinct constructs (25 percent overlap), whereas Duff et al. (2004) found a more substantial overlap (45 percent), mainly between openness and deep learning. In a study from 2012, von Stumm and Furnham suggested that learning approaches and personality traits, as measured by the "big five" model, share much of the variance, although not enough to render the notion of learning approach redundant.

Personality traits are also linked to academic performance. Vedel et al. (2015) found that conscientiousness predicted performance at university, a result that was confirmed in a Swedish study on upper secondary school students (Rosander, Backstrom \& Stenberg, 2011). However, extroversion and openness are better predictors of academic achievement in certain majors, where extroversion correlates negatively with academic achievement for psychology students and openness positively for social science students (Vedel et al., 2015). Further, in contrast to previous research, Rosander and Backstrom (2014) found that neuroticism is positively linked to academic performance. As they explained, the anxiety and vulnerability connected to the fear of failure the students experience may cause them to perform better.

\section{Personality and preference for teaching and learning activities and assessment modes}

Student personality traits also influence which types of teaching and learning activities and assessment methods students prefer. Chamorro-Premuzic et al. (2007) grouped activities into two categories: interactive activities involving more interaction and practical work, and less interactive and more traditional activities, such as lectures and independent study. Students who are more open, agreeable and emotionally stable prefer small group tutorials, lab classes and clinical training. Introverts also like independent study more than extrovert students do. Students with a deep learning approach also prefer interactive activities more than students with a surface approach do. Chamorro-Premuzic et al.'s (2007) study was performed on medical students at an elite institution in the United Kingdom. Therefore, it is interesting to see what preferences might be detected in students from other disciplines who are attending a teaching university rather than an elite research university.

There are also indications that students with different personality traits prefer different types of assessment modes (Furnham et al., 2011; Lakhal et al., 2013). For example, Furnham et al. (2011) found that students who are imaginative and deep learners prefer traditional assessment modes, such as essays. Open students with a deep strategy were shown to prefer dissertations, which students

with a surface approach did not. In addition, surface learners prefer multiple-choice questions. Stable extroverts prefer oral assessments, something that students high in neuroticism do not like.

Lakhal et al. (2013) explored personality and preferences for evaluation method among business students. They distinguished between thing-oriented (e.g., accounting, finance) and people-oriented (e.g., marketing, human resources, management) academic specializations. Female students were found to be more agreeable and conscientious than male students, and to prefer written exams and practical work. People-oriented students seemed to prefer case studies more than thing-oriented students did, and extrovert students indicated a higher preference for oral exams and group work. Higher scores on openness, conscientiousness and agreeableness indicated a higher preference for group work. Higher agreeableness scores indicated a lower preference for written 
examinations and a higher preference for practical work, case studies and projects. Students who scored higher on conscientiousness favored case studies less. Contrary to Furnham and ChamorroPremuzic (2005), Lakhal et al. (2013) found no correlation between neuroticism and dislike for oral and written exams.

The studies discussed above were limited to one major, and more research is needed to further explore the relationship between personality and preferences for teaching and learning activities and assessment modes. The present study aims to explore the personality profiles of two different majors, their learning approaches and preferences for teaching and learning activities and assessment modes.

\section{Learning, disjuncture, and risk}

According to Jarvis (2010), learning is a process of change, and a process that requires some degree of discomfort. The first step in a learning process comes from what Jarvis calls a disjuncture-when the student realizes that there is something wrong with how he or she understands the world, that is, that there is something that he or she cannot explain or perform. The discomfort of not understanding, not knowing or not being able to do something provides the motivation for learning. High-quality learning then results from gathering new information and actively reflecting based on the disjuncture, all in order to reach a new harmonious position where the disjuncture is solved-an explanation has been reached, a skill has been mastered. From the perspective of Jarvis's model for learning, the role of the teacher is to create disjuncture and to support the active reflections that lead students back to a new harmonious state.

In addition, Biesta (2005) discussed how learning involves discomfort, or even risk. Students risk learning things they did not intend to learn or could ever imagine learning. They may even learn things about themselves they would rather not have learned. Learning may change how one sees the world or oneself. Like Jarvis (2010), Biesta (2005) suggested that learning is initiated as a response to a question that creates disintegration. The aim of the learning process, then, is to reorganize and to reintegrate. Education should challenge students, pose difficult questions and create difficult situations, the goal being to initiate learning. From this perspective, a certain degree of discomfort with a teaching situation is not only acceptable, but also a prerequisite for high-quality learning.

\section{Challenges associated with teaching and personality}

What teaching or assessment methods are considered good depends on what environment teachers are in or their specific teaching and learning regime. According to Trowler (2008), Teaching and learning regimes are work groups that share certain taken-for-granted social norms, traditions and conventions regarding what constitutes an appropriate or inappropriate practice. Teaching and learning regimes develop over time, and members share common views on students, teaching and learning. These views and norms are linked to the subject area and members' epistemological views (BIåsjö, 2004). Introducing new teaching and learning activities or assessment methods may be difficult depending on the specific traits of the teaching and learning regime. This means that different academic majors may approach teaching and assessment in slightly different ways and that the dominant view of the teaching and learning regime may or may not include reluctance to challenge students, or to introduce new teaching and assessment modes.

Hence, we posit that it is important to understand the composition of student cohorts in different majors. One reason is that this may allow teachers to avoid inducing unnecessary anxiety among students by introducing teaching and learning activities students dislike or are not 
accustomed to. The second reason is that it may enable teachers to avoid making life too comfortable for students by always using teaching and learning activities and assessment methods teachers and students alike prefer, thereby running the risk of never challenging students.

\section{METHOD}

The present exploratory study was carried out in a Swedish teaching university among students in a business $(n=144)$ and preschool teacher education program $(n=179)$. The two programs were chosen because they were equivalent in size and the two student cohorts were also deemed to be different with regard to both the preferences of students and the teaching and learning regime of the program (Trowler, 2008).

\section{Measures}

\section{IPIP five-factor test}

Personality was measured using a Swedish version of the 120-item short form of the IPIPNEO-PI test (Goldberg, 1999), measuring the personality scales neuroticism, extroversion, openness to experience, conscientiousness, and agreeableness, with 24 items for each scale. The response format was a scale with five alternatives from 1 (not at all accurate) to 5 (very accurate). There is a rapidly expanding amount of literature (Goldberg et al., 2006) reporting studies that have included IPIP scales instead of commercial inventories, such as the NEO-PI-R (Costa \& McCrae, 1992). The IPIP scales correlated on average $r=$ 0.73 ( $r=.94$ when corrected for attenuation due to scale unreliability) with the NEO PI-R scales on which they were based (Johnson, 2014).

\section{The revised two-factor Study Process Questionnaire (R-SPQ-2F)}

The 20-item revised two-factor Study Process Questionnaire (R-SPQ.2F) was used to assess two main approaches to learning: a deep approach defined as "a real understanding of what has been learned", and a surface approach defined as "a reproduction of what has been taught to meet the minimum requirement" (Biggs et al., 2001). The response format was a scale with five alternatives from 1 (this item is never or only rarely true of me) to 5 (this item is always or almost always true of me). The construct approaches to learning model has a hierarchical structure, including both strategy and motive elements for each approach. Each strategy and motive element is itself multidimensional. Regarding its metric characteristics, a recent study (Shah et al., 2016) confirmed that the R-SPQ2F measures of deep and surface learning approaches have acceptable internal consistency coefficients ranging from 0.71 to 0.72 . This resembles the original validation study (Biggs, 2001), which found a similar internal consistency for the deep approach (0.73), but a slightly lower coefficient for the surface approaches to learning (0.64).

\section{Preference for teaching and learning activities and assessment modes}

Preference for teaching and learning activities and assessment modality was measured by asking students to choose the three teaching and learning activities and three assessment modes they preferred among a choice of modes. A total of eight teaching and learning activities were included: lecture, group discussion, seminar, role-play, workshop, online lecture, lab and work-integrated learning. In addition, the option "other" was included. The aim was to capture different modalities, ranging from directed instructions, as in the lecture, to independent and collaborative work and experience-based modes, such as lab work and work-integrated learning. 
A total of thirteen assessment modes were included: written assessment/essay questions, written assessment with multiple-choice questions, written assessment with mixed types of questions, individual oral presentation, individual written assignments, group written assignment, group oral presentation, seminar, case study, practical tests, role-play, lab work, journal/diary/written logbook. Here too the option "other" was included. The aim was to cover different types of assessment modes, from individual to group assessment, and from closed forms students could control (individual/written) to more open forms (group work). Contrary to previous studies (Chamorro-Premuzic et al., 2007; Furnham et al., 2011; Lakhal et al., 2013), the teaching and learning activities and assessment modes students had actually experienced were also controlled for in two separate questions asking them to indicate all the different teaching and assessment forms they had encountered during the course of their studies.

\section{Procedure and ethical considerations}

The questionnaires were administered electronically to students in a classroom setting. In accordance with the ethical guidelines of the university, students were in informed about procedure, informed consent and confidentiality in the storage and processing of the collected data. Each of the four test sessions lasted approximately half an hour.

\section{Analysis}

In the statistical analysis, individual two-tailed t-tests were used to test for group-level differences in preferences for assessment modes and teaching and learning activities, personality and learning approach/strategy. Differences were considered statistically significant if $\mathrm{p}<0.05$. Analyses were carried out using MATLAB 2016b (MathWorks, 2017).

Furthermore, a principal component analysis was carried out, with preference for assessment modes and teaching and learning activities as variables and with each student as an observation. Scores were normalized but not standardized prior to analysis. No weighting or post-processing factor rotation was used in the analysis. A singular-value decomposition algorithm was used to calculate the principal components, used as implemented in MATLAB.

\section{RESULTS}

\section{Descriptive statistics}

In the preschool teacher education program, 95 percent of students were female $(n=179)$. The median age was 24 and about 17 percent of students were born outside Sweden or had immigrant parents. Of the preschool teacher education students, at least 65 percent had at least one parent with a higher education.

The business administration major is organized into three specializations: international business and marketing, banking and finance, and accounting and auditing. In total, 59 percent of the business students were female and the business students were slightly younger than the preschool teacher education students $(\mathrm{Md}=22)$. The business students were also more likely to have both or one parent with a higher education. The percentage of students with an immigrant background was also slightly higher (18 percent) than in the preschool teacher education program (see table 2). 
Table 2. The sample

\begin{tabular}{|c|c|c|c|c|c|}
\hline & \multirow{2}{*}{$\begin{array}{l}\text { PRESCHOOL } \\
\text { TEACHER } \\
\text { EDUCATION }\end{array}$} & \multicolumn{4}{|c|}{ BUSINESS*** } \\
\hline & & IBM & $\mathrm{BF}$ & AA & All \\
\hline Number of respondents & 179 & 34 & 28 & 73 & 144 \\
\hline Percent women (\%) & 95 & 56 & 46 & 66 & 59 \\
\hline Age (median range) & 24 & 22 & 22 & 22 & 22 \\
\hline Born outside Sweden (\%) & 8.9 & 8.8 & 7.1 & 5.5 & 6.3 \\
\hline Parents born outside Sweden (\%) & 7.8 & 12 & 18 & 16 & 12 \\
\hline Academic background* $(\%)$ & 40 & 56 & 54 & 52 & 53 \\
\hline Academic background ${ }^{* *}(\%)$ & 25 & 41 & 61 & 47 & 49 \\
\hline
\end{tabular}

* The student's mother has a university level degree.

** The student's father has a university level degree.

*** Business program: IBM (international business and marketing specialization); AA (accounting and auditing specialization); BF (banking and finance specialization)

\section{Research question 1: Cohort level differences in personality profile}

Table 3 summarizes personality differences between the cohorts. There were significant differences between business and preschool teacher education students in all five dimensions: preschool teacher education students were lower in extroversion, openness, and conscientiousness, and higher on neuroticism and agreeableness. There was only one significant difference when comparing the three different business specializations to the business cohort as a whole: banking and finance students showed an even lower value on agreeableness than did business students in general.

Table 3. Mean score on the five personality dimensions by study program

\begin{tabular}{llllll}
\hline & $\begin{array}{l}\text { PRESCHOOL } \\
\text { TEACHER }\end{array}$ & \multicolumn{2}{l}{ BUSINESS**** } \\
\cline { 3 - 6 } & EDUCATION & IBM & BF & AA & All \\
\hline EXTRAVERSION & $3.32^{* * *}$ & 3.62 & 3.40 & 3.55 & 3.54 \\
NEUROTICISM & $2.81^{* * *}$ & 2.41 & 2.74 & 2.63 & 2.60 \\
OPENNESS & $3.29^{*}$ & 3.23 & 3.06 & 3.10 & 3.13 \\
AGREEABLENESS & $3.83^{* * *}$ & 3.66 & $3.40^{* *}$ & 3.74 & 3.64 \\
CONSCIENTIOUSNESS & $3.66^{* *}$ & 3.82 & 3.64 & 3.87 & 3.82 \\
\hline
\end{tabular}

* Significantly different from business (all) $(p<0.05)$.

** Significantly different from business (all) $(p<0.01)$.

***Significantly different from business (all) $(p<0.001)$.

**** Business program: IBM (international business and marketing specialization); AA (accounting and auditing specialization); BF (banking and finance specialization)

Because the preschool teacher education program had a high percentage of female students (95 percent), the same analysis was carried out on female students only in the whole sample (see table 4). Differences between the two majors remained when controlling for gender, but only significantly so for the three traits, extraversion, openness and conscientiousness. This means that in this sample, there were significant differences between the two majors on three out of five personality dimensions after controlling for gender. The difference within the business major remained, and female students from the banking and finance specialization also scored significantly lower on Agreeableness. 
Table 4. Mean score on the five personality dimensions by study program (women only)

\begin{tabular}{|c|c|c|c|c|c|}
\hline & \multirow{2}{*}{$\begin{array}{l}\text { PRESCHOOL } \\
\text { TEACHER } \\
\text { EDUCATION }\end{array}$} & \multicolumn{4}{|c|}{ BUSINESS**** } \\
\hline & & IBM & $\mathrm{BF}$ & $\mathrm{AA}$ & All \\
\hline Extroversion & $3.33^{*}$ & 3.62 & 3.44 & 3.52 & 3.53 \\
\hline Neuroticism & 2.81 & 2.53 & 2.99 & 2.73 & 2.73 \\
\hline Openess & $3.29^{*}$ & 3.32 & 3.12 & 3.13 & 3.16 \\
\hline Agreeableness & 3.85 & 3.79 & $3.45^{* *}$ & 3.87 & 3.77 \\
\hline Conscientiousness & $3.68^{* *}$ & 3.80 & 3.65 & 3.95 & 3.88 \\
\hline
\end{tabular}

* Significantly different from business (all) $(\mathrm{p}<0.05)$.

** Significantly different from business (all) $(p<0.01)$.

***Significantly different from business (all) $(p<0.001)$.

**** Business program: IBM (international business and marketing specialization); AA (accounting and auditing specialization); BF (banking and finance specialization)

\section{Research question 2: Cohort level differences in learning approach}

Table 5 compares the average score on learning approach, motive and strategy between the majors and within the business program. In general, preschool teacher education students showed higher motive, approach and strategy in relation to deep learning than most business students, and lower motive, approach and strategy in relation to surface learning. Within the business major, one of the study programs (banking and finance) also distinguished itself by showing significant differences compared to the other specializations. With regard to the deep/surface classification, banking and finance students were more extremely surface oriented than were the business students in general.

Table 5. Average score on learning approach by study program

\begin{tabular}{llllll}
\hline & $\begin{array}{l}\text { PRESCHOOL } \\
\text { TEACHER }\end{array}$ & \multicolumn{3}{l}{ BUSINESS**** } \\
\cline { 4 - 6 } & IBUCATION & & BF & AA & All \\
\hline Deep approach & $3.1^{*}$ & 3.1 & 2.7 & 3.0 & 3.0 \\
Surface approach & $2.3^{* * *}$ & 2.6 & $3.0^{* *}$ & 2.5 & 2.6 \\
Deep Motive & $3.2^{* *}$ & 3.1 & 2.8 & 3.0 & 3.0 \\
Deep Strategy & 3.0 & 3.1 & $2.6^{*}$ & 2.9 & 2.9 \\
Surface Motive & $2.1^{* *}$ & 2.4 & $2.8^{*}$ & 2.3 & 2.4 \\
Surface Strategy & $2.6^{* * *}$ & 2.7 & $3.3^{* *}$ & 2.8 & 2.9 \\
\hline
\end{tabular}

*Significantly different from business (all) $(\mathrm{p}<0.05)$.

**Significantly different from business (all) $(p<0.01)$.

***Significantly different from business (all) $(p<0.001)$.

**** Business program: IBM (international business and marketing specialization); $\mathrm{AA}$ (accounting and auditing specialization); BF (banking and finance specialization)

The same analysis of learning approach was carried out on female students only in the whole sample (see table 6). The significant differences remained (tables 5 and 6). Thus, the variance was not due to gender, but to differences in learning approach adopted by the students in the different study programs. Moreover, the variations within the business major remained. 
Table 6. Average score on learning approaches by study program (women only)

\begin{tabular}{|c|c|c|c|c|c|}
\hline & \multirow{2}{*}{$\begin{array}{l}\text { PRESCHOOL } \\
\text { TEACHER } \\
\text { EDUCATION }\end{array}$} & \multicolumn{4}{|c|}{ BUSINESS ***** } \\
\hline & & IBM & $\mathrm{BF}$ & $A A$ & All \\
\hline Deep approach & $3.1^{*}$ & 3.1 & 2.7 & 2.9 & 2.9 \\
\hline Surface approach & $2.3^{* * *}$ & 2.7 & $3.1^{*}$ & 2.5 & 2.6 \\
\hline Deep Motive & $3.2^{*}$ & 3.1 & 2.8 & 3.0 & 3.0 \\
\hline Deep Strategy & $3.1^{*}$ & 3.0 & $2.6^{*}$ & 2.8 & 2.9 \\
\hline Surface Motive & $2.1^{* *}$ & 2.5 & $2.8^{*}$ & 2.2 & 2.3 \\
\hline Surface Strategy & $2.5^{* * *}$ & 2.9 & $3.4^{*}$ & 2.8 & 2.9 \\
\hline
\end{tabular}

* Significantly different from business (all) $(p<0.05)$.

** Significantly different from business (all) $(p<0.01)$.

***Significantly different from business (all) $(p<0.001)$.

**** Business program: IBM (international business and marketing specialization); AA (accounting and auditing specialization); BF (banking and finance specialization)

\section{Research question 3: Cohort level differences in preferences for teaching and learning activities and assessment mode}

Table 7 summarizes the results for the percentage of students in the different cohorts preferring the different teaching and learning activities and assessment modes. It should be noted that not all students had experienced all of the different modes. The percentages in table 7, therefore, refer to the students in each cohort with experience of the corresponding mode. Table 7 shows that there were several significant differences in preferences between business students and preschool teacher education students. Most of the differences remained when controlling for gender, exploring the preferences in an all-female sample (see table 8).

Regarding teaching and learning activities, more business students preferred lectures, online lectures and workshops, whereas more preschool teacher education students preferred group discussions, seminars and work-integrated learning/internship. Regarding assessment modes, more business students preferred written examinations, and individual and group assignments, whereas preschool teacher education students preferred individual written assignments, seminars and oral group presentations. No significant differences in preferences for teaching and learning activities and assessment modes could be seen between the different academic specializations within the business major.

Table 7. Percentage of students with experience of an assessment form or a teaching and learning activity who preferred that form by study program

\begin{tabular}{|c|c|c|c|c|c|}
\hline \multirow[b]{3}{*}{ ASSESSMENT MODE } & \multirow{2}{*}{$\begin{array}{l}\text { PRESCHOOL } \\
\text { TEACHER } \\
\text { EDUCATION }\end{array}$} & \multicolumn{4}{|c|}{ BUSINESS $S^{* * * *}$} \\
\hline & & IBM & $\mathrm{BF}$ & $\mathrm{AA}$ & All \\
\hline & & & & & \\
\hline Written examination/essay questions & $22 \%{ }^{* * *}$ & $44 \%$ & $52 \%$ & $60 \%$ & $55 \%$ \\
\hline Written examination/multiple-choice & $11 \%{ }^{* * *}$ & $26 \%$ & $50 \%$ & $35 \%$ & $35 \%$ \\
\hline Written examination/mixed questions & $11 \%{ }^{* * *}$ & $47 \%$ & $59 \%$ & $77 \%$ & $66 \%$ \\
\hline Individual oral presentation & $3 \%{ }^{* * *}$ & $27 \%$ & $31 \%$ & $5 \%$ & $19 \%$ \\
\hline Individual written assignment & $82 \%^{* * *}$ & $53 \%$ & $30 \%$ & $43 \%$ & $44 \%$ \\
\hline Written group assignment & $42 \%$ & $44 \%$ & $37 \%$ & $49 \%$ & $44 \%$ \\
\hline Oral group presentation & $42 \%{ }^{* * *}$ & $29 \%$ & $28 \%$ & $10 \%$ & $18 \%$ \\
\hline
\end{tabular}




\begin{tabular}{|c|c|c|c|c|c|}
\hline Seminar & $42 \%{ }^{* * *}$ & $25 \%$ & $26 \%$ & $10 \%$ & $18 \%$ \\
\hline Case study & $13 \%$ & $6 \%$ & $12 \%$ & $3 \%$ & $6 \%$ \\
\hline Practical test & $23 \%$ & $20 \%$ & $0 \%$ & $0 \%$ & $9 \%$ \\
\hline Role-play & $10 \%$ & $8 \%$ & $0 \%$ & $0 \%$ & $5 \%$ \\
\hline Logbook/journal/diary & $2 \%$ & $0 \%$ & $0 \%$ & $8 \%$ & $4 \%$ \\
\hline $\mathrm{Lab}$ & $0 \%$ & $0 \%$ & $0 \%$ & $0 \%$ & $0 \%$ \\
\hline \multicolumn{6}{|l|}{ TEACHING AND LEARNING ACTIVITIES } \\
\hline Lecture & $79 \%^{* *}$ & $88 \%$ & $93 \%$ & $90 \%$ & $90 \%$ \\
\hline Group discussions & $78 \%{ }^{* * *}$ & $48 \%$ & $38 \%$ & $30 \%$ & $37 \%$ \\
\hline Seminar & $74 \%{ }^{* * *}$ & $55 \%$ & $33 \%$ & $36 \%$ & $42 \%$ \\
\hline Role-play & $21 \%$ & $7 \%$ & $0 \%$ & $0 \%$ & $4 \%$ \\
\hline Workshop & $0 \%{ }^{* * *}$ & $64 \%$ & $83 \%$ & $82 \%$ & $78 \%$ \\
\hline Online lectures & $15 \%{ }^{*}$ & $32 \%$ & $0 \%$ & $36 \%$ & $31 \%$ \\
\hline $\mathrm{Lab}$ & $8 \%$ & $0 \%$ & $25 \%$ & $0 \%$ & $9 \%$ \\
\hline Work-integrated learning/internship & $69 \%{ }^{* * *}$ & $26 \%$ & $40 \%$ & $51 \%$ & $43 \%$ \\
\hline
\end{tabular}

*Significantly different from business (all) $(p<0.05)$.

**Significantly different from business (all) $(p<0.01)$.

***Significantly different from business (all) $(p<0.001)$.

**** Business program: IBM (international business and marketing specialization); AA (accounting and auditing specialization); BF (banking and finance specialization)

Table 8. Percentage of students with experience of an assessment form or a teaching and learning activity who preferred that form by study program (women only)

\begin{tabular}{|c|c|c|c|c|c|}
\hline \multirow{3}{*}{ ASSESSMENT MODE } & \multirow{3}{*}{$\begin{array}{l}\text { PRESCHOOL } \\
\text { TEACHER } \\
\text { EDUCATION }\end{array}$} & \multicolumn{4}{|c|}{ BUSINESS**** } \\
\hline & & \multirow[t]{2}{*}{ IBM } & \multirow[t]{2}{*}{$\mathrm{BF}$} & \multirow[t]{2}{*}{ AA } & \multirow[t]{2}{*}{ All } \\
\hline & & & & & \\
\hline Written examination/essay questions & $21 \% * * *$ & $56 \%$ & $42 \%$ & $60 \%$ & $58 \%$ \\
\hline Written examination/multiple-choice & $11 \% *$ & $29 \%$ & $40 \%$ & $26 \%$ & $30 \%$ \\
\hline Written examination/mixed questions & $11 \% *$ & $41 \%$ & $50 \%$ & $74 \%$ & $62 \%$ \\
\hline Individual oral presentation & $3 \% * * *$ & $25 \%$ & $40 \%$ & $0 \%$ & $17 \%$ \\
\hline Individual written assignment & $83 \% * * *$ & $59 \%$ & $23 \%$ & $43 \%$ & $44 \%$ \\
\hline Written group assignment & $43 \%$ & $53 \%$ & $46 \%$ & $49 \%$ & $48 \%$ \\
\hline Oral group presentation & $42 \%{ }^{* *}$ & $19 \%$ & $42 \%$ & $15 \%$ & $20 \%$ \\
\hline Seminar & $42 \% * * *$ & $18 \%$ & $31 \%$ & $10 \%$ & $17 \%$ \\
\hline Case study & $11 \%$ & $9 \%$ & $11 \%$ & $0 \%$ & $5 \%$ \\
\hline Practical test & $23 \%$ & $17 \%$ & $0 \%$ & $0 \%$ & $8 \%$ \\
\hline Role-play & $9 \%$ & $0 \%$ & $0 \%$ & $0 \%$ & $0 \%$ \\
\hline Logbook/journal/diary & $2 \%$ & $0 \%$ & $0 \%$ & $11 \%$ & $7 \%$ \\
\hline $\mathrm{Lab}$ & $0 \%$ & $0 \%$ & $0 \%$ & $0 \%$ & $0 \%$ \\
\hline \multicolumn{6}{|l|}{ TEACHING AND LEARNING ACTIVITIES } \\
\hline Lecture & $79 \%$ ** & $100 \%$ & $92 \%$ & $90 \%$ & $92 \%$ \\
\hline Group discussions & $78 \%$ *** & $32 \%$ & $55 \%$ & $25 \%$ & $31 \%$ \\
\hline Seminar & $74 \%$ *** & $53 \%$ & $25 \%$ & $35 \%$ & $39 \%$ \\
\hline Role-play & $20 \%$ & $13 \%$ & $0 \%$ & $0 \%$ & $7 \%$ \\
\hline Workshop & $0 \%$ & $63 \%$ & $92 \%$ & $84 \%$ & $81 \%$ \\
\hline Online lectures & $13 \%$ & $39 \%$ & $0 \%$ & $28 \%$ & $29 \%$ \\
\hline
\end{tabular}




\begin{tabular}{llllll} 
Lab & $8 \%$ & $0 \%$ & $0 \%$ & $0 \%$ & $9 \%$ \\
Work-integrated learning/internship & $68 \%^{* *}$ & $33 \%$ & $29 \%$ & $50 \%$ & $44 \%$ \\
\hline
\end{tabular}

* Significantly different from business (all) $(p<0.05)$.

**Significantly different from business (all) $(p<0.01)$.

***Significantly different from business (all) $(\mathrm{p}<0.001)$.

**** Business program: IBM (international business and marketing specialization); AA (accounting and auditing specialization); BF (banking and finance specialization)

When comparing the modes preferred by students in the two majors, there seems to be a systematic difference between the types of modes preferred. Figure 1 illustrates this difference further using a principal component analysis biplot, showing the correlation between the preference for each teaching and learning activity and assessment mode. The principal component analysis biplot illustrates the principal differences in terms of preferred assessment modes and teaching and learning activities between the two majors, but also between the three business specializations. A square marker represents each assessment form and teaching and learning activity. The median position and an ellipse with halfaxes mark each major equal to the standard deviation in the corresponding principal component.

The figure suggests that preferences for some of the assessment modes are highly correlated; for example, the preference for written examinations of different types (far right of the figure) correlates with the preference for work-integrated learning and written group assessment (bottom of the figure). When applying principal component analysis, it is often meaningful to give an overall interpretation of each component by looking at which variables it is most highly correlated with.

This indicates that students with high a value on the first component (horizontal axis in figure 1) preferred traditional teaching and learning activities such as lectures and written examinations and did not prefer group discussions and assessments. Students with a high value on the second component (vertical axis in figure 1) preferred written group assessment to seminars.

Figure 1. Preferred assessment modes and teaching and learning activities, using a principal component analysis biplot

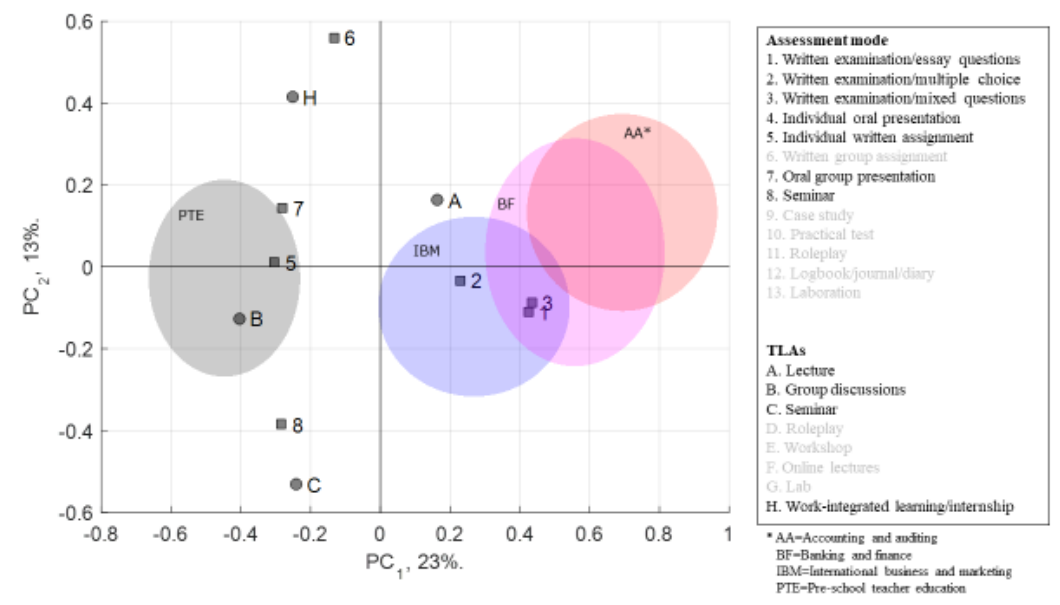

In this overall representation of the differences in preferred assessment modes and teaching and learning activities, using a principal component analysis biplot, each circle represents an assessment mode and each square a teaching and learning activity. The elliptical disks represent the variation in preferences for each student cohort, with the center given by the cohort mean and 
semiaxes given by two times the standard error for each cohort. To improve readability, only the assessment modes and teaching and learning activities that a majority of the students had experienced were included in the figure.

This interpretation can be used to further clarify the difference in preferences between the different majors (preschool teacher education and business) and within the business cohort. In Figure 1 , each cohort has been inserted into the principal component analysis biplot and is represented by a marker, indicating the average position of the cohort, and an ellipse corresponding to twice the standard error of the cohort. The ellipse could be thought of as the range, i.e., the confidence interval expressed in the first two components of the principal component analysis) of preferences for each cohort. As seen in figure 1, the difference in the first component between the business specializations and preschool teacher education major suggests that the business students showed a higher preference for the traditional modes. Some less pronounced differences could be seen between the different business specializations. The accounting and auditing students showed a slightly more extreme preference for the traditional modes and the international business and marketing students were more similar to the preschool teacher education students.

\section{Research question 4: To what extent can student personality trait profiles explain preferences for different assessment modes?}

The two majors differed in terms of both teaching and learning activities and which assessment modes preferred, and in personality. Based on previous studies (e.g., ChamorroPremuzic et al., 2007; Furnham et al., 2011), it could be hypothesized that the cohort level difference in preferences is modulated by differences in personality. Table 9 investigates differences in personality (across majors) between those who preferred a mode and those who did not. A positive value in table 9 indicates that a person with a high score in this personality dimension is more likely to prefer the indicated teaching and learning activity or assessment mode.

Table 9 indicates that openness, agreeableness, and conscientiousness modulated differences in preference. A high openness score corresponded to a lower preference for written assessment with multiple-choice questions and for lectures. A higher score on Agreeableness corresponded to a higher preference for group discussions, but a lower preference for written assessment with multiple-choice or mixed questions and a lower preference for individual oral presentation. Lastly, a higher score on conscientiousness corresponded to a higher preference for lectures and for written assessment with open-ended questions. If we compare the mean personality score in the five dimensions between students who preferred the assessment mode or teaching and learning activity to those who did not prefer it, a positive score means that those who preferred an activity had a higher score in this dimensions and were, thus, more likely to prefer the activity. The same analysis was carried out on women only, where much of the variance remained (see table 9A in the appendix).

The question is if the relations we see between personality and preferences for teaching and learning activities and assessment modes depend on a difference in personality or preference between the different majors. Table 9 displays the difference in personality between students who prefer specific assessment modes and teaching and learning activities and those who do not. However, when the groups shown in table 9 are sorted by major (preschool teacher education and business), only one of the significant effects as displayed in table 9 remains: a high score on openness decreases the preference for lectures as a teaching mode (see tables $9 \mathrm{~B}$ and $9 \mathrm{C}$ in the appendix). 


\begin{tabular}{|c|c|c|c|c|c|}
\hline & $\begin{array}{l}\text { 음 } \\
\text { 岀 } \\
\text { 这 } \\
\text { 妾 }\end{array}$ & 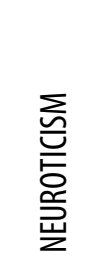 & 岕 & 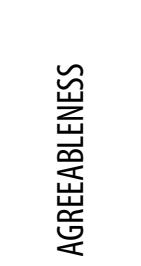 & 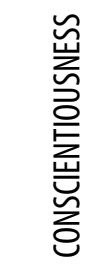 \\
\hline \multicolumn{6}{|l|}{ ASSESSMENT MODE } \\
\hline 1. Written examination/essay questions & $0.07^{* *}$ & -0.11 & -0.08 & 0.01 & $0.17^{* *}$ \\
\hline 2. Written examination/multiple-choice & -0.03 & -0.05 & $-0.22^{* * *}$ & $-0.18^{* * *}$ & -0.08 \\
\hline 3. Written examination/mixed questions & 0.12 & -0.14 & -0.14 & $-0.16^{* * *}$ & 0.07 \\
\hline 4. Individual oral presentation & 0.18 & -0.09 & 0.25 & $-0.25^{* *}$ & -0.08 \\
\hline 5. Individual written assignment & -0.08 & 0.05 & 0.07 & 0.07 & -0.10 \\
\hline 6. Written group assignment & 0.07 & 0.08 & -0.11 & 0.08 & 0.01 \\
\hline 7. Oral group presentation & -0.01 & 0.10 & 0.09 & 0.08 & -0.07 \\
\hline 8. Seminar & -0.08 & 0.07 & 0.07 & 0.05 & 0.01 \\
\hline 9. Case study & -0.31 & 0.21 & 0.12 & -0.19 & -0.17 \\
\hline 10. Practical test & NA & NA & NA & NA & NA \\
\hline 11. Role-play & NA & NA & $\mathrm{NA}$ & $\mathrm{NA}$ & NA \\
\hline 12. Logbook/journal/diary & NA & NA & NA & NA & NA \\
\hline 13. Lab & 0.17 & -0.16 & 0.03 & 0.00 & 0.09 \\
\hline \multicolumn{6}{|l|}{ TEACHING AND LEARNING ACTIVITIES } \\
\hline A. Lecture & 0.03 & -0.12 & $-0.27^{* * *}$ & -0.05 & $0.22^{* *}$ \\
\hline B. Group discussions & -0.04 & 0.13 & 0.12 & $0.12^{* * *}$ & -0.09 \\
\hline C. Seminar & 0.04 & -0.02 & 0.11 & 0.11 & 0.06 \\
\hline D. Role-play & NA & NA & NA & NA & NA \\
\hline E. Workshop & NA & NA & NA & NA & NA \\
\hline F. Online lectures & NA & NA & NA & NA & NA \\
\hline G. Lab & NA & NA & NA & NA & NA \\
\hline H. Work-integrated learning/internship & -0.07 & 0.03 & 0.07 & 0.07 & -0.11 \\
\hline
\end{tabular}

$\mathrm{NA}=$ too few respondents.

* Significantly different from business (all) $(p<0.05)$.

** Significantly different from business (all) $(p<0.01)$.

***Significantly different from business (all) $(p<0.001)$.

\section{DISCUSSION}

There seemed to be a systematic difference between the types of modes preferred between majors. Business students preferred traditional teaching and learning activities such as lectures, online lectures, and workshops more than did preschool teacher education students, who to a greater extent preferred group discussions, seminars, and work-integrated learning or internships. 
This difference was true also in terms of assessment modes. Preschool teacher education students preferred seminars and oral group presentations, as well as individual written examinations, whereas business students preferred written assessments and individual oral assessment. There were no significant differences in preferences between the different business specializations, although the principal component analysis biplot indicates that the international business and marketing students were more similar to the preschool teacher education students in their preferences than to the two other business specializations. This seems to be in line with Lakhal et al. (2013,) who found a difference between the preferences of students from thing-oriented (e.g. accounting) and people-oriented (e.g., marketing) academic specializations.

There were also significant differences regarding learning approach, motive, and strategy within the business program. In general, preschool teacher education students showed higher motive, approach, and strategy in relation to deep learning than did business students, and lower motive, approach, and strategy in relation to surface learning. Within the business major, one of the specializations (banking and finance) was more extremely surface oriented than business students were in general, also when controlling for gender.

How can these differences be explained? The study reveals significant differences between the personality profiles of the different majors. Preschool teacher education students were more neurotic, open, and agreeable than the business students. Other studies have also found business students to be less agreeable than students in other majors (Vedel et al., 2015). In most cultures, female students have also been found to be more agreeable and less emotionally stable, more extroverted and conscientious (Lakhal et al., 2013). Given that 95 percent of the preschool teacher education students were female, there is a risk that the differences in personality profile found are due to gender differences. However, several significant differences between the majors in this study remained when controlling for gender. This result may mean either that there was no difference, or that that there was a difference, but that sample was not large enough to measure such a difference. This means we must be careful about generalizing the present results.

The business students were found to be more extroverted, emotionally stable, and conscientious than the preschool teacher education students, which is in line with previous research (Lakhal et al., 2013). The preschool teacher education students were also found to be more open than the business students. Regarding openness, prior research has provided contradictory results; one study found that business students scored higher than education students on openness, but another that business students scored lower than non-business majors on openness (Vedel, 2016).

In sum, there seem to be differences between the personality profiles of the two different majors, and these can explain preferences for different assessment modes to some extent. In the present study, a high openness score corresponded to a lower preference for written assessment with multiple-choice questions and for lectures. A higher score on agreeableness corresponded to a higher preference for group discussions, but a lower preference for written assessment with multiple-choice or mixed questions as well as a lower preference for individual oral presentation. Lastly, a higher score on conscientiousness corresponded to a higher preference for lectures and for written assessment with open-ended questions.

In general, the preschool teacher education students showed higher motive, approach and strategy in relation to deep learning than business students did, and lower motive, approach and strategy in relation to surface learning. This could partly be explained by the fact that the preschool teacher 
education students were more open and agreeable, and a high score in openness correlated positively with both deep motive and strategy. Likewise, students with a high score on agreeableness were less inclined to prefer a surface strategy and motive and achieving motive. However, the preschool teacher education students scored higher than did the business students on neuroticism, which is empirically linked to a surface approach (Chamorro-Premuzic \& Furnham, 2009; Diseth, 2003). The business students were less open and agreeable, and less deep and more surface oriented overall than were the preschool teacher education students, even after controlling for gender. Students in one of the academic specializations in the business major, banking and finance, scored significantly lower on Agreeableness than did the other two business specializations. They were also more extremely surface oriented, which is in line with Chamorro-Premuzic and Furnham (2009), who found that agreeableness was negatively and significantly correlated with both surface strategy and motive and achieving motive.

Although there were significant differences between the groups regarding personality profile and learning approach, it is important to note that there was variation in personality traits among students within groups but also overlap between groups. Even so, the results may be interpreted as indicating that there are certain personality profiles for certain groups, which may affect "the feel" of the group as a whole, or how the group responds to certain teaching and learning activities and assessment modes. Vedel et al.'s (2015) study showed that different personality traits predicted academic success in different majors. However, there are few studies on the topic and more research is needed. Still, this may mean that students with certain personality traits fare better in some educational settings than in others, and the present findings may provide some guidance for teachers and pedagogical developers. Being aware of how the personality compositions of different groups vary, between and within groups, is important if we wish to make more students feel comfortable with their choice of study program and potentially help more students achieve academic success.

Psychological research has put forward that learning approach and personality traits, as measured by the five personality traits, share much of the variance. Still, learning approach cannot be considered a trait (von Stumm \& Furnham, 2012), as traits are relatively stable over time (McCrae \& Costa, 2003). This means that teaching and learning activities and assessment modes may steer students in different directions regarding choice of learning approach. However, one possible suggestion, based on the present study, is that it is not as easy to make students take a different approach as is sometimes portrayed in the teaching literature.

The question is whether these preferences are there from the start or whether students adapt to the teaching and learning regime, and the teaching and assessment style of their chosen major. This question is impossible for us to answer, as the present study is based on observational data. However, we found significant differences in preferences for learning style within the business major, where students in the banking and finance specialization were significantly more surface oriented than students in the two other specializations. Given that all three specializations share all classes the first year and partly in the second and third year, may indicate that these differences are due at least in part to personality and not solely to the teaching and learning regime of that specific specialization or major.

Notwithstanding, the result of the present study revealed significant differences. Teachers could benefit from being aware of the extra challenge posed by the personality composition of different groups, meaning that teaching to encourage a deep learning approach may not be futile, but may be considerably more challenging in certain groups and for certain individuals in groups than has been acknowledged in the literature. Kember (2004) also pointed out that teaching may affect both individual and overall class 
behavior, although this is often not clarified in the literature on approaches to learning. However, it is important to remember that changes at the class level in learning approach scores are small compared to the variation in individual scores within the class.

The questions remains if there is interaction between personality and program regarding preference for teaching and learning activities and assessment mode. When we divided the results by major only one significant effect remained. There are two possible interpretations. One might be that the major is the underlying variable, and that business students and preschool teacher education students have different personalities and preferences, but that there is really no interaction between personality and preference. However, this interpretation is contradicted by new significant relations that arose between personality and preferences when the two majors were analyzed separately (see tables 9B and $9 \mathrm{C}$ in the appendix). Another possible, and the most plausible interpretation, is that as we divided the material, the cell sizes were too small which limited the possibility to conduct statistical analyses. Hence, the effect must be larger for interaction effects to be visible in the tests.

\section{Implications for teaching and curriculum development}

This study implies there are differences in personality profiles and preferences for teaching and learning activities and assessment modes in different cohorts and majors. There are also different traditions, norms and values concerning what constitutes good teaching and learning in different work groups or teaching and learning regimes (Trowler, 2008). Hence, there are two clear risks that teachers and curriculum developers face. First, teachers who are new or come from a different teaching and learning regime may run the risk of alienating students and exposing them to extreme anxiety if they use teaching and learning activities and assessment modes students are uncomfortable and unfamiliar with. As we could see in the results, certain cohorts have certain personality profiles, which make them more prone to prefer or dislike, for example, group work or individual written examinations. If teachers were aware of the personality profile of the student cohort, they could perhaps better prepare students for new modes that may cause discomfort in some.

Second, teachers and curriculum developers run the risk of not challenging students enough, thus of depriving them of valuable learning experiences. According to the views of Jarvis (2010) and Biesta (2005), experiencing dissonance, discomfort and being challenged are essential prerequisites for learning. In an age of growing utilization of course evaluations to assess teacher performance, there is a risk that teachers, without reflection, will conform to using the teaching and learning activities and assessment modes that students prefer. The present study also shows that there are significant differences in the teaching and learning activities and assessment modes students from the different cohorts have actually experienced. This raises the question of how teachers choose teaching and learning activities. Following Jarvis's (2010) learning model, the optimal choice would be a teaching and learning activity that creates suitable disjuncture and the best opportunities for reflective learning from these situations. However, there is a risk that the choice has more to do with traditions within each teaching and learning regime. This problem could be especially pronounced in a Swedish university setting, where the number of internally recruited academic teachers is exceptionally high. Taking into account the personality-linked preference differences seen in the present results, one might with good reason fear that many higher education teachers are individuals who, as students, prospered with the teaching and learning activities preferred in their specific teaching and learning regime. This may lead to reinforcement of differences in teaching practice that have more to do with tradition and less with student learning. 


\section{Limitations and future research}

The limitations of the present study include the fact that it is a single-site study; multi-site studies would have been preferable and would have enabled generalization of the results. In addition, only two study programs were included. A multi-site study including several different study programs would broaden the picture. Another limitation regards the influence of gender in the present study. Differences between the majors in this study remained when controlling for gender. However, it is important to note that this result may mean either that there was no difference when controlling for gender, or that that there was a difference, but when we excluded the male students, the sample was not large enough to measure such a difference. This means we must be careful about generalizing the present results; we can only point to significant differences in this specific study sample.

Nevertheless, the results indicate that there are differences in personality profiles and preferences for teaching and learning activities and assessment modes between different cohorts and majors, and thus they have implications for teaching and curriculum development. Further investigation into what preferences teachers in these teaching and learning regimes have, and how they think about choosing teaching and learning activities and assessment modes, would be an interesting continuation of this study.

\section{ACKNOWLEDGMENTS}

We would like to thank the editor of this journal and the anonymous reviewers whose constructive feedback contributed significantly to the completion of this paper.

Annika Fjelkner is a lecturer and pedagogical developer in the Faculty of business at Kristianstad University (SE).

Andreas Håkansson is an associate professor and director of undergraduate studies at the department of food engineering in the Faculty of Engineering, Lund University, Faculty of Engineering (SE). His main research is in the hydrodynamics of food processing equipment.

Pia Rosander is assistant professor in psychology and vice-dean of the Faculty of Teacher Education, Kristianstad University (SE). Her main research is in personality psychology.

\section{REFERENCES}

Biesta, G. (2005). Against learning: Reclaiming a language for education in an age of learning. Nordisk Pedagogik, 25(1), 54-66. Retrieved from https://www.ltu.se/cmsfs/1.123949!/file/Article+Biesta+against+learning.pdf

Biggs, J. B. (1987). Student approaches to learning and studying. Hawthorn, Victoria, AU: Australian Council for Educational Research.

Biggs, J. B. (2001). Enhancing learning: A matter of style or approach? In R. J. Sternberg, \& L. F. Zhang, Perspectives of thinking, learning and cognitive styles (pp. 73-102). Mahwah, NJ: Lawrence Erlbaum Associates.

Biggs J. B., Kember, D. \& Leung, D. Y. P. (2001). The revised two-factor Study Process Questionnaire: R-SPQ-2F. British Journal of Educational Psychology, 71(1), 133-149. https://doi.org/10.1348/000709901158433

Biggs, J. \& Tang, C. (2011). Teaching for quality learning at university (4th ed.) New York, NY: McGraw Hill.

Blåsjö, M. (2004). Studenters skrivande i två kunskapsbyggande miljöer. Stockholm, SE: Almqvist \& Wiksell International.

Campbell, A. R. \& Dickson, C. J. (1996). Predicting student success: a 10-year review using integrative review and meta-analysis. Journal of Professional Nursing, 12(1), 47-59. https://doi.org/10.1016/S8755$\underline{7223(96) 80074-3}$ 
Chamorro-Premuzic, T. \& Furnham, A. (2008). Personality, intelligence and approaches to learning as predictors of academic performance. Personality and Individual Differences, 44(7), 1596-1603.

https://doi.org/10.1016/j.paid.2008.01.003

Chamorro-Premuzic, T. \& Furnham, A. (2009). Mainly openness: The relationship between the Big Five personality traits and learning approaches. Learning and Individual Differences, 19(4), 524-529. https://doi.org/10.1016/j.lindif.2009.06.004

Chamorro-Permuzic, T., Furnham, A. \& Lewis, M. (2007). Personality and approaches to learning predict preferences for different teaching methods. Learning and Individual Differences, 17(3), 241-250. https://doi.org/10.1016/j.lindif.2006.12.001

Costa, P. T. \& McCrae, R. R. (1992). Revised NEO personality inventory (NEO-PI-R) and NEO five-factor inventory (NEOFFI): Professional manual. Odessa, FL: Psychological Assessment Resources.

Diseth, A. (2003). Personality and approaches to learning as predictors of academic achievement. European Journal of Personality, 17(2), 143-155. https://psycnet.apa.org/doi/10.1002/per.469

Duff, A., Boyle, E., Dunleavy, K. \& Ferguson, J. (2004). The relationship between personality, approach to learning and academic performance. Personality and Individual Differences, 36(8), 1907-1920. https://doi.org/10.1016/j.paid.2003.08.020

Elmgren, M. \& Henriksson, A.-S. (2016). Universitetspedagogik. Lund, SE: Studentlitteratur.

Furnham, A., Batey, M. \& Martin, N. (2011). How would you like to be evaluated? The correlates of students' preferences for assessment methods. Personality and Individual Differences, 50(2), 259-263. https://doi.org/10.1016/j.paid.2010.09.040

Furnham, A. \& Charmorro-Premuzic, T. (2005). Individual differences and beliefs concerning preferences for university assessment methods. Journal of Applied Social Psychology, 35(9), 1968-1994. https://doi.org/10.1111/j.1559-1816.2005.tb02205.x

Furnham, A., Monsen, J. \& Ahmetoglu, G. (2009). Typical intellectual engagement, Big Five personality traits, approaches to learning and cognitive ability predictors of academic performance. British Journal of Educational Psychology, 79(4), 769-782.https://doi.org/10.1348/978185409X412147

Goldberg, L. R. (1999). A broad-bandwidth, public domain, personality inventory measuring the lower-level facets of several five-factor models. In D. I. Mervielde, F. De Fruyt, \& F. Ostendorf, Personality Psychology in Europe: Vol. 7. Selected papers from the eighth European Conference on Personality, held in Ghent, Belgium, July 1996 (pp. 7-28). Tilburg, NL: Tilburg University Press.

Goldberg, L. R., Eber, H. W., Hogan, R., Ashton, M. C., Cloninger, C. R. \& Gough, H. G. (2006). The international personality item pool and the future of public-domain personality measures. Journal of Research in Personality, 40(1), 84-96.https://doi.org/10.1016/j.jrp.2005.08.007

Haarala-Muhonen, A., Ruohoniemi, M., Parpala, A. K., \& Lindblom-Ylanne, S. (2017). How do the different study profiles of first-year students predict their study success, study progress and the completion of degrees? Higher Education, 74(6), 949-962.https://doi.org/10.1007/s10734-016-0087-8

Holland, J. L. (1997). Making vocational choices: A theory of vocational personality and work environments (3rd ed.). Odessa, FL: Psychological Assessment Resources.

Hollander, M. A. \& Parker, H. J. (1972). Occupational stereotypes and self-descriptions: Their relationship to vocational choice. Journal of Vocational Behaviour, 2(1), 57-65. https://doi.org/10.1016/0001$\underline{8791(72) 90007-3}$

Jarvis, P. (2010). Adult education and lifelong learning: Theory and practice. London, UK: Routledge.

Johnson, J. A. (2014). Measuring thirty facets of the Five Factor Model with a 120-item public domain inventory: Development of the IPIP-NEO-120. Journal of Research in Personality, 51, 78-89. https://doi.org/10.1016/j.jrp.2014.05.003

Kahu, E. R. (2013). Framing student engagement in higher education. Studies in Higher Education, 38(5), 758-773. https://doi.org/10.1080/03075079.2011.598505

Kember, D. (2004). Interpreting student workload and the factors which shape students' perceptions of their workload. Studies in Higher Education, 29(2), 165-184. https://doi.org/10.1080/0307507042000190778

Kember, D., Biggs, J. \& Leung, D. Y. P. (2004). Examining the multidimensionality of approaches to learning through the development of the Learning Process Questionnaire. British Journal of Educational Psychology, 74(2), 261-280.https://doi.org/10.1348/000709904773839879 
Krause, K.-L., Hartley, R., James, R. \& McInnis, C. (2005). The first year experience in Australian universities: Findings from a decade of national studies. Melbourne, AU: Centre for the Study of Higher Education University of Melbourne.

Kuh, G. D. (2009). What student affairs professionals need to know about student engagement. Journal of College Student Development, 50(6), 683-706.http://dx.doi.org/10.1353/csd.0.0099

Kuncel, N. R., Crecle, M. \& Thomas, L. L. (2007). A meta-analysis of the predictive validity of the graduate management admission test (GMAT) and undergraduate grade point average (UGPA) for graduate student academic performance. Academy of Management Learning \& Education, 6(1), 51-68. https://doi.org/10.5465/amle.2007.24401702

Lakhal, S., Sevigny, S. \& Frenette, E. (2013). Personality and preferences for evaluation methods: A study among business administration students. Studies in Educational Evaluation, 39(2), 103-115. https://doi.org/10.1016/j.stueduc.2013.02.002

Lounsbury, J. W., Smith, R. M., Levy, J. J., Leong, F. T. \& Gibson, L. W. (2009). Personality characteristics of business majors as defined by the big five and narrow personality traits. Journal of Education for Business, 84(4), 200-205. http://dx.doi.org/10.3200/JOEB.84.4.200-205

Marton, F. \& Saljo, R. (1976). On qualitative differences in learning-1: Outcomes and processes. British Journal of Educational Psychology, 46(1), 4-11.https://doi.org/10.1111/j.2044-8279.1976.tb02980.x

MathWorks. (2017). MATLAB. Retrieved from https://se.mathworks.com/

McCrae, R. R. \& Costa, P. (1997). Conceptions and correlates of openness to experience. In R. Hogan, J. A. Johnson \& S. R. Briggs, Handbook of personality psychology (pp. 825-847). San Diego, CA: Academic Press.

McCrae, R. R., \& Costa P. T. (2003). Personality in adulthood: A five-factor theory perspective (2nd ed.). New York, NY: Guilford Press.

McKenzie, K. \& Schweitzer, R. (2001). Who succeeds at university? Factors predicting academic performance in first year Australian university students. Higher Education Research \& Development, 20(1), 21-33. http://dx.doi.org/10.1080/07924360120043621

Ramsden, P. (2003). Learning to teach in higher education (2nd ed.) London, UK: RoutledgeFalmer.

Rosander, P. \& Backstrom, M. (2014). Personality traits measures at baseline can predict academic performance in upper secondary school three years later. Scandinavian Journal of Psychology, 55(6), 611-618. https://doi.org/10.1111/sjop.12165

Rosander, P., Backstrom, M. \& Stenberg, G. (2011). Personality traits and general intelligence as predictors of academic performance: A structural equation modelling approach. Learning and Individual Differences, 21(5), 590-596. https://doi.org/10.1016/j.lindif.2011.04.004

Schaie, K. W. (1986). Beyond calendar definitions of age, time, and cohort: The general developmental model revisited. Developmental Review, 6(3), 252-277. https://doi.org/10.1016/0273-2297(86)90014-6

Shah, D. K., Yadav, R. L., Sharma, D., Yadav, P. K., Sapkota, N. K., Jha, R. K. \& Islam N. (2016). Learning approach among health sciences students in a medical college in Nepal: A cross-sectional study. Advances in Medical Education and Practice, 7, 137-143. https://doi.org/10.2147/AMEP.S100968

Simpson, O. (2006). Predicting student success in open and distance learning. Open Learning: Journal of Open, Distance and E-learning, 21(2), 125-138. https://doi.org/10.1080/02680510600713110

Svinicki, M. D. \& McKeachie, W. J. (2014). McKeachie's teaching tips: Strategies, research, and theory for college and university teaching. Belmont, CA: Wadsworth Cengage Learning.

Swanberg, A. B. \& Martinsen, O. J. (2010). Personality, approaches to learning and achievement. Educational Psychology, 30(1), 75-88. http://dx.doi.org/10.1080/01443410903410474

Thomas, L. (2012). Building student engagement and belonging at a time of change: Final report from the What Works? Student Retention and Success Programme. York, UK: Higher Education Academy. Retrieved from https://www.heacademy.ac.uk/system/files/what works final report.pdf

Trowler, P. (2008). Cultures and change in higher education: Theories and practice. London, UK: Palgrave Macmillan. Trowler, P. \& Trowler, V. (2010). Student engagement evidence summary. York, UK: Higher Education Academy.

Vedel, A. (2016). Big Five personality group differences across academic majors: a systematic review. Personality and Individual Differences, 92, 1-10. https://doi.org/10.1016/j.paid.2015.12.011

Vedel, A., Thomsen, D. \& Larsen, L. (2015). Personality, academic major and performance: Revealing complex patterns. Personality and Individual Differences, 85, 69-76. https://doi.org/10.1016/j.paid.2015.04.030 
Von Stumm, S., \& Furnham, A. (2012). Learning approaches: Associations with Typical Intellectual Engagement, intelligence and the Big Five. Personality and Individual Differences, 53(5), 720-723.

https://doi.org/10.1016/j.paid.2012.05.014

Yorke, M. (2004). Retention, persistence and success in on-campus higher education, and their enhancement in open and distance learning. Open Learning, 19(1), 19-32. https://doi.org/10.1080/0268051042000177827

Yorke, M. \& Longden, B. (2008). The first-year experience of higher education in the UK. York, UK: Higher Education Academy. Retrieved from https://www.heacademy.ac.uk/system/files/fyefinalreport 0.pdf

Zhang, L. F. (2003). Does the big five predict learning approaches? Personality and Individual Differences, 34(8), 1431-1446. https://doi.org/10.1016/S0191-8869(02)00125-3

\section{APPENDIX: TABLES 9A-C. PERSONALITY AND PREFERENCES FOR TEACHING AND LEARNING ACTIVITIES AND ASSESSMENT MODES}

Tables 9A-C display the difference in personality between students who prefer specific assessment modes and teaching and learning activities and those who do not, for women only (9A), teacher education students only (9B) and business students only (9C).

Table 9A. Personality and preferences for teaching and learning activities and assessment modes (women only)

\begin{tabular}{|c|c|c|c|c|c|}
\hline & $\begin{array}{l}\text { 은 } \\
\text { 苫 } \\
\underset{\mathbf{c}}{\mathbf{x}} \\
\text { 妾 }\end{array}$ & 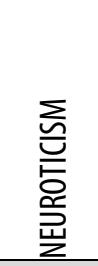 & 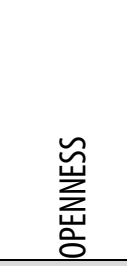 & 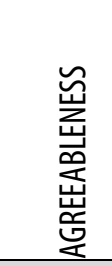 & 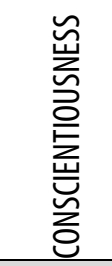 \\
\hline \multicolumn{6}{|l|}{ ASSESSMENT MODE } \\
\hline 1. Written examination/essay questions & $0.10^{*}$ & -0.12 & -0.02 & 0.07 & $0.19^{* *}$ \\
\hline 2. Written examination/multiple-choice & -0.06 & -0.01 & -0.11 & $-0.13^{*}$ & -0.09 \\
\hline 3. Written examination/mixed questions & 0.07 & -0.05 & -0.11 & -0.03 & 0.09 \\
\hline 4. Individual oral presentation & 0.20 & -0.04 & 0.18 & -0.18 & 0.02 \\
\hline 5. Individual written assignment & $-0.17^{*}$ & 0.05 & 0.04 & 0.01 & $-0.15^{*}$ \\
\hline 6. Written group assignment & 0.11 & 0.09 & -0.12 & 0.05 & 0.02 \\
\hline 7. Oral group presentation & 0.04 & 0.05 & 0.02 & -0.01 & -0.05 \\
\hline 8. Seminar & -0.06 & 0.05 & 0.00 & -0.02 & -0.01 \\
\hline 9. Case study & -0.14 & 0.21 & 0.27 & -0.24 & $-0.33^{*}$ \\
\hline 10. Practical test & NA & $\mathrm{NA}$ & NA & NA & $\mathrm{NA}$ \\
\hline 11. Role-play & NA & $\mathrm{NA}$ & $\mathrm{NA}$ & NA & NA \\
\hline 12. Logbook/journal/diary & NA & NA & $\mathrm{NA}$ & NA & NA \\
\hline 13. Lab & 0.19 & -0.23 & 0.00 & -0.08 & 0.08 \\
\hline \multicolumn{6}{|l|}{ TEACHING AND LEARNING ACTIVITIES } \\
\hline A. Lecture & 0.10 & -0.14 & $-0.23^{* *}$ & -0.02 & $0.19^{*}$ \\
\hline B. Group discussions & -0.07 & 0.12 & 0.02 & 0.05 & -0.08 \\
\hline C. Seminar & 0.05 & -0.03 & 0.12 & 0.08 & 0.00 \\
\hline D. Role-play & NA & NA & $\mathrm{NA}$ & NA & NA \\
\hline E. Workshop & NA & NA & NA & NA & NA \\
\hline F. Online lectures & NA & $\mathrm{NA}$ & $\mathrm{NA}$ & NA & $\mathrm{NA}$ \\
\hline G. Lab & $\mathrm{NA}$ & $\mathrm{NA}$ & $\mathrm{NA}$ & NA & $\mathrm{NA}$ \\
\hline H. Work-integrated learning/internship & -0.02 & -0.03 & 0.05 & 0.05 & -0.09 \\
\hline
\end{tabular}


$N A=$ too few respondents.

* Significantly different from business (all) $(\mathrm{p}<0.05)$.

** Significantly different from business (all) $(\mathrm{p}<0.01)$.

*** Significantly different from business (all) $(p<0.001)$.

Table 9B. Personality and preferences for teaching and learning activities and assessment modes (preschool teacher education students only)

\begin{tabular}{|c|c|c|c|c|c|}
\hline & $\begin{array}{l}\text { 은 } \\
\text { 苫 } \\
\text { 这 } \\
\text { 悹 }\end{array}$ & 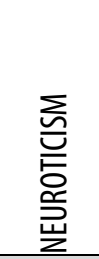 & $\begin{array}{l}\text { 峛 } \\
\text { 흥 }\end{array}$ & 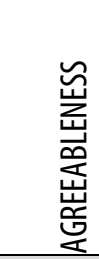 & 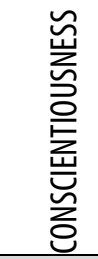 \\
\hline \multicolumn{6}{|l|}{ ASSESSMENT MODE } \\
\hline 1. Written examination/essay questions & 0.12 & $\begin{array}{l}- \\
0.22^{*}\end{array}$ & 0.03 & 0.09 & 0.12 \\
\hline 2. Written examination/multiple-choice & -0.01 & -0.05 & -0.08 & -0.11 & $-0.25^{*}$ \\
\hline 3. Written examination/mixed questions & 0.06 & -0.11 & -0.14 & -0.13 & -0.07 \\
\hline 4. Individual oral presentation & 0.18 & -0.14 & 0.21 & -0.12 & 0.22 \\
\hline 5. Individual written assignment & -0.06 & 0.12 & 0.03 & 0.00 & -0.12 \\
\hline 6. Written group assignment & 0.01 & 0.12 & -0.13 & 0.09 & 0.02 \\
\hline 7. Oral group presentation & -0.03 & 0.12 & -0.06 & -0.02 & -0.03 \\
\hline 8. Seminar & -0.01 & 0.01 & -0.05 & 0.01 & 0.14 \\
\hline 9. Case study & -0.39 & 0.21 & -0.02 & -0.25 & -0.23 \\
\hline 10. Practical test & NA & NA & NA & NA & NA \\
\hline 11. Role-play & NA & $\mathrm{NA}$ & NA & $\mathrm{NA}$ & NA \\
\hline 12. Logbook/journal/diary & NA & NA & NA & $\mathrm{NA}$ & NA \\
\hline 13. Lab & 0.56 & -0.02 & $0.92^{*}$ & -0.12 & -0.37 \\
\hline \multicolumn{6}{|l|}{ TEACHING AND LEARNING ACTIVITIES } \\
\hline A. Lecture & 0.07 & -0.17 & $-0.21^{* *}$ & 0.01 & $0.22^{*}$ \\
\hline B. Group discussions & 0.06 & 0.10 & -0.10 & $0.15^{*}$ & 0.01 \\
\hline C. Seminar & $0.21^{* *}$ & -0.09 & 0.10 & 0.09 & $0.19^{*}$ \\
\hline D. Role-play & NA & NA & NA & NA & NA \\
\hline E. Workshop & NA & $\mathrm{NA}$ & NA & NA & NA \\
\hline F. Online lectures & NA & $\mathrm{NA}$ & NA & $\mathrm{NA}$ & NA \\
\hline G. Lab & NA & NA & NA & NA & NA \\
\hline H. Work-integrated learning/internship & -0.05 & -0.09 & -0.05 & 0.02 & -0.04 \\
\hline
\end{tabular}

$\mathrm{NA}=$ too few respondents.

* Significantly different from business (all) $(p<0.05)$.

** Significantly different from business (all) $(\mathrm{p}<0.01)$.

*** Significantly different from business (all) $(p<0.001)$. 


\begin{tabular}{|c|c|c|c|c|c|}
\hline & 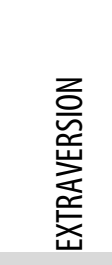 & 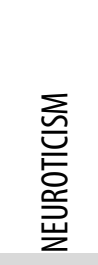 & 岕 & 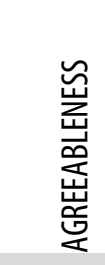 & 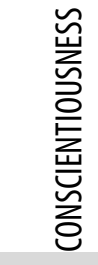 \\
\hline \multicolumn{6}{|l|}{ ASSESSMENT MODE } \\
\hline 1. Written examination/essay questions & -0.11 & 0.11 & -0.07 & 0.08 & 0.12 \\
\hline 2. Written examination/multiple-choice & $-0.17^{*}$ & 0.05 & $-0.24^{* * *}$ & $-0.15^{*}$ & -0.07 \\
\hline 3. Written examination/mixed questions & -0.05 & 0.01 & -0.02 & -0.04 & 0.01 \\
\hline 4. Individual oral presentation & 0.10 & 0.01 & $0.33^{*}$ & $-0.25^{*}$ & $-0.29^{*}$ \\
\hline 5. Individual written assignment & 0.07 & $-0.18^{*}$ & -0.02 & -0.01 & 0.02 \\
\hline 6. Written group assignment & 0.12 & 0.06 & -0.07 & 0.08 & -0.02 \\
\hline 7. Oral group presentation & $0.28^{* *}$ & -0.14 & $0.27^{*}$ & 0.11 & 0.00 \\
\hline 8. Seminar & -0.06 & 0.02 & 0.17 & -0.03 & -0.09 \\
\hline 9. Case study & -0.11 & 0.17 & 0.33 & -0.13 & -0.03 \\
\hline \multicolumn{6}{|l|}{ 10. Practical test } \\
\hline \multicolumn{6}{|l|}{ 11. Role-play } \\
\hline \multicolumn{6}{|l|}{ 12. Logbook/journal/diary } \\
\hline 13. Lab & -0.06 & -0.12 & -0.20 & 0.11 & 0.18 \\
\hline \multicolumn{6}{|l|}{ TEACHING AND LEARNING ACTIVITIES } \\
\hline A. Lecture & -0.22 & 0.14 & $-0.31^{*}$ & -0.04 & 0.12 \\
\hline B. Group discussions & 0.07 & 0.01 & $0.23^{* *}$ & -0.04 & -0.05 \\
\hline C. Seminar & 0.01 & -0.09 & 0.02 & 0.03 & 0.06 \\
\hline \multicolumn{6}{|l|}{ D. Role-play } \\
\hline \multicolumn{6}{|l|}{ E. Workshop } \\
\hline \multicolumn{6}{|l|}{ F. Online lectures } \\
\hline \multicolumn{6}{|l|}{ G. Lab } \\
\hline H. Work-integrated learning/internship & 0.09 & 0.00 & 0.08 & -0.02 & -0.07 \\
\hline
\end{tabular}

$\mathrm{NA}=$ too few respondents.

* Significantly different from business (all) $(p<0.05)$.

** Significantly different from business (all) $(p<0.01)$.

*** Significantly different from business (all) $(p<0.001)$. 


Copyright for the content of articles published in Teaching \& Learning Inquiry resides with the
authors, and copyright for the publication layout resides with the journal. These copyright holders
have agreed that this article should be available on open access under a Creative Commons Attribution License 4.0
International (https://creativecommons.org/licenses/by/4.0). The only constraint on reproduction and distribution, and
the only role for copyright in this domain, should be to give authors control over the integrity of their work and the
right to be properly acknowledged and cited, and to cite Teaching \& Learning Inquiry as the original place of publication.
Readers are free to share these materials-as long as appropriate credit is given, a link to the license is provided, and
any changes are indicated.

